\title{
Tolerance level of different life stages of Nile tilapia Oreochromis niloticus (Linnaeus, 1758) to low pH and acidified waters
}

\author{
Moshood K. Mustapha* and Samuel D. Atolagbe
}

\begin{abstract}
Background: Acidification or acid rain in freshwater ecosystem is increasing especially in developing countries due to modernization, urbanization and population increase. An effect of acid deposition on water bodies is the lowering of the $\mathrm{pH}$, which affects fish species negatively. This study evaluated tolerance levels of different life stages of Oreochromis niloticus to different acidic pH as it affects their survival, morphology and behaviour. Concentrated sulphuric acid was used for the acidification. Four hundred fifty $O$. niloticus of different life stages of fingerlings, juveniles and adults were stocked in the different acidic pHs in triplicates for 14 days.

Results: Fingerling mortalities were $100 \%, 96 \%, 70 \%$ and $42 \%$ in pH 3, 4, 5 and 6 . One hundred percent, 44\%, 22\% and $12 \%$ juvenile mortalities were noted in $\mathrm{pH} 3,4,5$, and 6 , respectively. One hundred percent, 34\%, $18 \%$ and $14 \%$ adult mortalities were recorded in $\mathrm{pH} 3,4,5$ and 6 , respectively. Tolerance of 0 . niloticus to low pH was Adult > juvenile $>$ fingerlings. Morphological and behavioural changes observed include erratic swimming, gasping, slimy mucous secretions, skin erosion, bleeding of fins, impairment in feeding and lethargy. Mortality was attributed to acid stress, acidosis of the blood, erosion of the epidermal layers, sodium ion influx inhibition and ionoregulatory system failure.
\end{abstract}

Conclusion: Mortalities, behavioural responses and morphological abnormalities recorded in O. niloticus were due to the toxic effect of the acid on the body physiology. Adult O. niloticus can be described as acid-tolerant species (acidophilic). For the culture of the species, the pH of the water should be regularly checked for acidity, and the fish should be reared at optimal pH similar or better than the one in which the fish were brought (i.e. from a fish farm) in order to prevent metabolic stress and for the survival of the species in culture.

Keywords: Acid, Stress, Survival, Mortality, Morphology, Behaviour

\section{Background}

The culture of Nile tilapia Oreochromis niloticus in pond culture system in Nigeria usually involves the use of fry, fingerling, juvenile and sometimes adult fish which are often sourced from wild waters such as streams, lakes, rivers and reservoirs or bought from fish farms. High mortalities of many of the different life stages of the fish sourced from the wild for stocking in fish rearing ponds have been recorded. Among several factors that could cause the mortality is inadequate acclimatization of the fish to new culture medium and non-optimization of the rearing ponds to the ideal $\mathrm{pH}$ conditions. This is often

\footnotetext{
* Correspondence: moonstapha@yahoo.com

Department of Zoology, University of Ilorin, PMB 1515, Ilorin 240003, Nigeria
}

neglected as a cause of mortality during breeding. In most fish ponds, the ideal water $\mathrm{pH}$ of 6-9 are usually provided for fish breeding without considering the $\mathrm{pH}$ of the habitat from where the fish were sourced and the optimal $\mathrm{pH}$ for culturing the fish.

Cases of acid deposition and acidification of most aquatic habitats have been documented (Baker et al., 1996; Sivaramanan, 2015). This phenomenon also referred to as acid rain is increasing especially in developing countries where modernization, urbanization and population increase have been a major driving force to the effect. One of the effects of acid deposition on water bodies is the lowering of the $\mathrm{pH}$ levels, which consequently decreases fish population (Baker et al., 1996). But in spite of acid deposition in these lakes and rivers, 
many fish species are known to live and adapt to the acidic waters. One of such fish species is Mozambique tilapia, Oreochromis mossambicus, which has some mechanisms for adaptation to acidic water (Rebouças, Lima, Cavalcante, \& Sá, 2015). Likewise, the tambaqui, Colossoma macropomum, shows increase growth in acidic waters and is negatively affected by waters with pH above 8 (Aride, Roubach, \& Val, 2007). Similarly, Tribolodon hakonensis, a cyprinid teleost, lives and grows in the extremely acidic $\mathrm{pH}$ between $3.4-3.8$ (Hirata et al., 2003).

To avoid mortality of newly stocked fish in ponds, acclimatization and culture of the species should be done at optimal $\mathrm{pH}$ in order to prevent metabolic stress. According to El-Sherif and El-Feky (2009), the optimal range of water $\mathrm{pH}$ for rearing Nile tilapia, Oreochromis niloticus, is between 7 and 8. However, recent data by Nobre, Lima and Magalhães (2014) suggest that the optimal range of water $\mathrm{pH}$ for farming Nile tilapia juveniles ranges from 5 to 8 , with the species adapting and growing well in moderately acidic waters. Similarly, Rebouças et al. (2015) and Wangead, Geater and Tansakul (1988) reported O. niloticus juveniles that showed better growth performance, high survival and low mortality rates when reared in acidic waters as low as $\mathrm{pH} 4$.

The aim of this study was to evaluate the tolerance levels of different life stages of Nile tilapia O. niloticus (a very important fish of culture) to different low $\mathrm{pH}$ and acidified waters as it affect their survival, morphology, behaviour and subsequent rearing in aquacultural ponds.

\section{Materials and methods Experimental design}

Four experimental pHs (3, 4, 5 and 6) and a control $\mathrm{pH}$ (8.01) in triplicates of each $\mathrm{pH}$ were used for the experiment. Concentrated sulphuric acid was used for acidification of the culture media. The sulphuric acid was added to deionized water to make stock $\mathrm{pH}$-adjusted solution water. This was to ensure that the $\mathrm{pH}$ would not change over the period of the experiment due to evaporation, precipitation or with the addition of deionized water. Forty litres of $\mathrm{pH} 3,4,5$ and 6 for the stock solution was prepared by serial dilution using the acid and deionized water. Hanna portable pH/EC/TDS/ Temperature combined water proof tester/meter model HI 98129 was used to test the pH levels of each stock solution. The control $\mathrm{pH}$ was borehole water having a $\mathrm{pH}$ of 8.01. Daily readings of the $\mathrm{pH}$ in the treatment tanks were performed at 8.00 am and $6.00 \mathrm{pm}$ using the Hanna portable pH/EC/TDS/Temperature combined water proof tester/meter model HI 98129.

\section{Experimental fish stocking and treatment}

A total of 450 Oreochromis niloticus specimens were used for the experiment comprising of fingerlings (average weight of $2.2 \mathrm{~g} \pm 0.01$ ), juveniles (average weight of $18.6 \mathrm{~g} \pm 0.02$ ) and adults (average weight of $300 \mathrm{~g} \pm 0.05$ ). For each fish stages (fingerlings, juveniles and adults), 10 fish were stocked in a 40-1 tank $(1 \times 1 \times 0.2 \mathrm{~m})$ of acidified water of $\mathrm{pH} \mathrm{3,4,5}$, and 6 as well as the control with a base $\mathrm{pH}$ of 8.01 which is the $\mathrm{pH}$ of the water in which the fishes were sourced. They were slowly acclimatized to the experimental treatments of the acidified waters of $\mathrm{pH} \mathrm{3,4,5}$ and 6 , respectively, for 7 days before the start of the experiment. The fishes were fed with coppens fish feed twice daily $(8.00 \mathrm{am}$ and $6.00 \mathrm{pm})$ at $5 \%$ of their biomass. The experiment was conducted for 14 days at the Department of Zoology, University of Ilorin, Ilorin, Nigeria.

\section{Data collection}

Survival of the fish was evaluated daily by counting of surviving fish in each tank. Tactile and visual observations were carried out daily to observe morphological and behavioural changes that occurred due to the effect of different concentration of the acids on the different life stages of the fish.

\section{Statistical analysis}

Statistical analyses of fish survival were made through the one-way ANOVA, at $P<0.05$. The statistical analyses were run with SPSS $20.0^{\circ}$ statistical package (Armonk, New York, USA).

\section{Results}

\section{Mortalities of different life stages}

After 14 days of exposure of the fingerlings to $\mathrm{pH} \mathrm{3,4,5}$ and 6 , the following mortalities were recorded: $100 \%$ in $\mathrm{pH} 3,96 \%$ in $\mathrm{pH} 4,70 \%$ in $\mathrm{pH} 5$ and $42 \%$ in $\mathrm{pH} 6$, while the mortality in the control $\mathrm{pH}$ was $16 \%$ (Table 1). All the fingerlings in $\mathrm{pH} 3$ died immediately they were stocked, the fingerlings in $\mathrm{pH} 4$ died between 1 and 5 days, those in $\mathrm{pH} 5$ died between 3 and 8 days, while

\begin{tabular}{|c|c|c|c|c|}
\hline $\mathrm{pH}$ treatment & No. exposed & Days of exposure & Survival & Survival \% \\
\hline 3 & 50 & 14 & $0 \pm 0^{a}$ & $0 \pm 0^{a}$ \\
\hline 4 & 50 & 14 & $2 \pm 0^{b}$ & $4 \pm 0^{b}$ \\
\hline 5 & 50 & 14 & $15 \pm 0^{c}$ & $30 \pm 0^{c}$ \\
\hline 6 & 50 & 14 & $29 \pm 0^{d}$ & $58 \pm 0^{d}$ \\
\hline 8 & 50 & 14 & $42 \pm 0^{e}$ & $84 \pm 0^{e}$ \\
\hline
\end{tabular}

Mean values in the same column with different superscript are significantly different $(p<0.05)$ 
those in pH 6 died between 4 and 12 days. In the control $\mathrm{pH}$, death of the fingerlings was recorded between 7 and 14 days.

A similar scenario was seen among the juveniles where $100 \%$ mortality was observed in $\mathrm{pH} 3$. Forty-four percent, $22 \%$ and $12 \%$ mortalities of the juveniles were noted in $\mathrm{pH} 4,5$, and 6 , respectively, while juvenile mortality in the control $\mathrm{pH}$ was $8 \%$ (Table 2). The time of death of the juveniles in the different acidic media is also shown in Table 2.

One hundred percent mortality was also recorded for the adult stocked in $\mathrm{pH} 3$ with all the fish dying on the first day. Between 3 and 9 days of stocking in $\mathrm{pH} 4$, $34 \%$ of the adult died, while $18 \%$ and $14 \%$ mortalities were found in pHs 5 and 6 , respectively, with the deaths observed between 5 and 14 days of exposure. Only $4 \%$ mortality of the adult was observed in the control pH (Table 3). There were significant differences $(P<0.05)$ in the mortality rates among the different life stages of the species in the different pHs. The trend of the tolerance of different life stages of O. niloticus to low $\mathrm{pH}$ and acidified water was Adult > juvenile > fingerlings.

\section{Morphological and behavioural changes}

Morphological and behavioural changes observed in the fingerlings, juveniles and adults especially in $\mathrm{pH} 4$ and 5 include erratic swimming, accelerated operculum movement leading to gasping, barbells vibration and frequent coming to the surface. Very dark body colouration and slimy mucous secretions were observed on the gills and body surface; peeling and skin erosion were also noted. There was bleeding from the dorsal fins and bending of the caudal fin, some fins became disintegrated and impairment in feeding was observed. Confinement to the bottom of the tanks, with movement occurring when agitated and in one direction, swimming speed was reduced in juvenile and adults, impairment in feeding and lethargy were the other behavioural responses seen in the different life stages of the fish under $\mathrm{pH} 4$ and 5 (Tables 4, 5 and 6).

Table 2 Mean survival of $O$. niloticus juveniles in low $\mathrm{pH}$ and control $\mathrm{pH}$

\begin{tabular}{lllll}
\hline $\mathrm{pH}$ treatment & No. exposed & Days of exposure & Survival & Survival \% \\
\hline 3 & 50 & 14 & $0 \pm 0^{\mathrm{a}}$ & $0 \pm 0^{\mathrm{a}}$ \\
4 & 50 & 14 & $28 \pm 0^{\mathrm{b}}$ & $56 \pm 0^{\mathrm{b}}$ \\
5 & 50 & 14 & $39 \pm 0^{\mathrm{c}}$ & $78 \pm 0^{c}$ \\
6 & 50 & 14 & $44 \pm 0^{\mathrm{d}}$ & $88 \pm 0^{\mathrm{d}}$ \\
8 & 50 & 14 & $46 \pm 0^{\mathrm{e}}$ & $92 \pm 0^{\mathrm{e}}$ \\
\hline
\end{tabular}

Mean values in the same column with different superscript are significantly different $(p<0.05)$
Table 3 Mean survival of $\mathrm{O}$. niloticus adults in low $\mathrm{pH}$ and control pH

\begin{tabular}{lllll}
\hline $\mathrm{pH}$ treatment & No. exposed & Days of exposure & Survival & Survival \% \\
\hline 3 & 50 & 14 & $0 \pm 0^{\mathrm{a}}$ & $0 \pm 0^{\mathrm{a}}$ \\
4 & 50 & 14 & $33 \pm 0^{\mathrm{b}}$ & $66 \pm 0^{\mathrm{b}}$ \\
5 & 50 & 14 & $41 \pm 0^{\mathrm{c}}$ & $82 \pm 0^{\mathrm{c}}$ \\
6 & 50 & 14 & $43 \pm 0^{\mathrm{d}}$ & $86 \pm 0^{\mathrm{d}}$ \\
8 & 50 & 14 & $48 \pm 0^{\mathrm{e}}$ & $96 \pm 0^{\mathrm{e}}$ \\
\hline
\end{tabular}

Mean values in the same column with different superscript are significantly different $(p<0.05)$

\section{Discussion}

Acidification of natural fish habitat as a result of anthropogenic pollution of oxides of sulphur and nitrogen is increasing especially in developing countries where there are no laws or regulations to curb the incidence. Majority of the fish species used for aquaculture are sourced from the wild and hatcheries of fish farms, and most of these fish species are cultured based on standard water quality guidelines without considering the habitat from which the fish was sourced, the tolerance $\mathrm{pH}$ level of the species, as well as the suitable $\mathrm{pH}$ for the culture of the species. According to McKee and Wolf (1963), the acceptable range of $\mathrm{pH}$ to fish depends on prior $\mathrm{pH}$ acclimatization.

The optimal $\mathrm{pH}$ for the rearing and survival of different fish species ranges. The USEPA (1986) concluded that a $\mathrm{pH}$ range of 6.5 to 9.0 provides adequate protection for the life of freshwater fish. Outside this range, fish suffer adverse physiological effects that increase in severity as the degree of deviation increases until lethal levels are reached. Alabaster and Lloyd (1980) identified the $\mathrm{pH}$ range that is not directly lethal to freshwater fish as 5.0-9.0, while Wood and McDonaild (1982) stated that effects of chronic exposure of fish to low $\mathrm{pH}$ are minimal at $\mathrm{pH} 4$ and 6 . It should however be noted that optimal $\mathrm{pH}$ range for fish also depend on the species, the life stage of the species and other interacting water quality conditions.

All the different life stages of the Nile tilapia Oreochromis niloticus did not survive in acidified water of $\mathrm{pH} 3$ in this work. This could be due to toxic action of hydrogen ions which affected oxygen uptake leading to acid stress, precipitation of proteins within the epithelial cells and/or acidosis of the blood (Boyd, 1990). It could also be probably attributable to erosion of the epidermal layer of the integument and gills, sodium ion influx inhibition (Duarte, Ferreira, Wood, \& Val, 2013), brain, kidney and spleen injury, lysis of erythrocytes as reported by Daye and Garside (1980) and Hill et al. (1988)) and failure of the ionoregulatory system leading to circulatory collapse (Peterson \& Martin-Robichaud, 1986). Incomplete development of the ion regulation 
Table 4 Morphological and behavioural observations of fingerling of O. niloticus in low $\mathrm{pH}$ and control

\begin{tabular}{|c|c|c|c|c|c|}
\hline Observations & $\mathrm{pH} 3$ & $\mathrm{pH} 4$ & $\mathrm{pH} 5$ & $\mathrm{pH} 6$ & Control \\
\hline Morphological & $\begin{array}{l}\text { None as mortality } \\
\text { was recorded }\end{array}$ & $\begin{array}{l}\text { Very dark body } \\
\text { colouration, slimy mucous } \\
\text { secretions on the gills and } \\
\text { body surface; peeling } \\
\text { and skin erosion, bleeding } \\
\text { from the dorsal fins and } \\
\text { bending of the caudal } \\
\text { fin, some fins became } \\
\text { disintegrated }\end{array}$ & $\begin{array}{l}\text { Very dark body } \\
\text { colouration, slimy mucous } \\
\text { secretions on the gills and } \\
\text { body surface; peeling and } \\
\text { skin erosion, bleeding } \\
\text { from the dorsal fins and } \\
\text { bending of the caudal } \\
\text { fin, some fins } \\
\text { became disintegrated }\end{array}$ & $\begin{array}{l}\text { Normal body colouration } \\
\text { except some few dark } \\
\text { patches, no morphological } \\
\text { abnormalities observed. }\end{array}$ & $\begin{array}{l}\text { Normal body colouration, } \\
\text { no morphological } \\
\text { abnormalities seen }\end{array}$ \\
\hline Behavioural & $\begin{array}{l}\text { None as mortality } \\
\text { was recorded }\end{array}$ & $\begin{array}{l}\text { Lethargy, they were } \\
\text { confined to the bottom } \\
\text { of the tanks and only } \\
\text { moved when agitated } \\
\text { with the movement } \\
\text { being in one direction, } \\
\text { feeding impaired } \\
\text { Swimming velocity } \\
\text { decreased }\end{array}$ & $\begin{array}{l}\text { Lethargy, they were } \\
\text { confined to the bottom } \\
\text { of the tanks and only } \\
\text { moved when agitated } \\
\text { with the movement } \\
\text { being in one direction, } \\
\text { feeding impaired } \\
\text { Swimming velocity } \\
\text { decreased }\end{array}$ & $\begin{array}{l}\text { Movement not impaired, } \\
\text { they were seen on the } \\
\text { surface of tanks, no } \\
\text { abnormal behavioural } \\
\text { activities observed }\end{array}$ & $\begin{array}{l}\text { Normal movement and } \\
\text { behavioural responses } \\
\text { observed }\end{array}$ \\
\hline
\end{tabular}

system among the fingerlings might have underlie their reduced acid tolerance (Daye \& Garside, 1980). Wangead et al. (1988) observed that fingerlings, juvenile and adult tilapias did not survive when subjected to $\mathrm{pH} 3$ water.

High percentage rate of fingerling mortalities in $\mathrm{pH} 4$ and 5 could be attributed to the above reasons, while their minimal survival was attributed to their increasing adaptation to the acidified water. Survival of the juveniles and adults in $\mathrm{pH} 4,5$ and 6 was attributed to efficient ion transportation systems which allowed them to maintain a more effective salt balance than the fingerlings, while mortality could be as a result of ionoregulatory failure (Peterson \& Martin-Robichaud, 1986) in body salt regulation leading to haemoconcentration and circulatory collapse (Mount, Hockett, \& Gern, 1988), as well as the inability of the haemoglobin to uptake oxygen (Wood \& McDonaild, 1982). The mortality could also be due to production of mucus on the gill epithelium, which interferes with the exchange of respiratory gasses and ions across the gill. Hence, respiratory distress and osmotic imbalance were culpable as the primary physiological symptoms that lead to acid stress in the fish. The survival rates of the juveniles and adults in $\mathrm{pH} 4,5$ and 6 were similar to that of Wangead et al. (1988), but slightly differ from that of Rebouças et al. (2015). The tolerance level of acidity seen in the different life stages of the species agrees with Rask (1984) who stated that $\mathrm{pH}$ tolerance of fish increases with age of the fish. It therefore showed that $O$. niloticus could be cultured in acidified water as reported by Rebouças et al. (2015) and this should be taken into consideration when breeding the species in aquaculture ponds most especially if the species is taken from the acidified wild waters.

The behavioural responses and morphological abnormalities such as erratic swimming, accelerated operculum movement leading to gasping, barbells vibration, very dark body colouration and slimy mucous secretions on the gills and body surface, peeling and erosion of the skin, bleeding from the dorsal fins, bending of the caudal

Table 5 Morphological and behavioural observations of juvenile of O. niloticus in low pH and control

\begin{tabular}{|c|c|c|c|c|c|}
\hline Observations & $\mathrm{pH} 3$ & $\mathrm{pH} 4$ & $\mathrm{pH} 5$ & $\mathrm{pH} 6$ & Control \\
\hline Morphological & $\begin{array}{l}\text { None as } \\
\text { mortality was } \\
\text { recorded }\end{array}$ & $\begin{array}{l}\text { Very dark body colouration, } \\
\text { slimy mucous secretions on } \\
\text { the gills and body surface; } \\
\text { peeling and skin erosion, } \\
\text { bleeding from the dorsal } \\
\text { fins and bending of the } \\
\text { caudal fin, some fins } \\
\text { became disintegrated }\end{array}$ & $\begin{array}{l}\text { Very dark body colouration, } \\
\text { slimy mucous secretions on } \\
\text { the gills and body surface; } \\
\text { peeling and skin erosion, } \\
\text { bleeding from the dorsal } \\
\text { fins and bending of the } \\
\text { caudal fin, some fins } \\
\text { became disintegrated }\end{array}$ & $\begin{array}{l}\text { Normal body colouration } \\
\text { except some few dark } \\
\text { patches, no } \\
\text { morphological } \\
\text { abnormalities recorded. }\end{array}$ & $\begin{array}{l}\text { Normal body colouration, } \\
\text { no morphological } \\
\text { abnormalities seen }\end{array}$ \\
\hline Behavioural & $\begin{array}{l}\text { None as } \\
\text { mortality was } \\
\text { recorded }\end{array}$ & $\begin{array}{l}\text { Erratic swimming, } \\
\text { accelerated operculum, } \\
\text { gasping, barbells vibration } \\
\text { and frequent coming } \\
\text { to the surface, feeding } \\
\text { impaired } \\
\text { Swimming velocity } \\
\text { decreased }\end{array}$ & $\begin{array}{l}\text { Erratic swimming, } \\
\text { accelerated operculum, } \\
\text { gasping, barbells vibration } \\
\text { and frequent coming to } \\
\text { the surface, feeding } \\
\text { impaired, Swimming } \\
\text { velocity decreased }\end{array}$ & $\begin{array}{l}\text { No behavioural } \\
\text { abnormalities observed. }\end{array}$ & $\begin{array}{l}\text { Normal movement and } \\
\text { behavioural responses } \\
\text { observed }\end{array}$ \\
\hline
\end{tabular}


Table 6 Morphological and behavioural observations of adult of O. niloticus in low $\mathrm{pH}$ and control

\begin{tabular}{|c|c|c|c|c|c|}
\hline Observations & $\mathrm{pH} 3$ & $\mathrm{pH} 4$ & $\mathrm{pH} 5$ & $\mathrm{pH} 6$ & Control \\
\hline Morphological & $\begin{array}{l}\text { None as mortality } \\
\text { was recorded }\end{array}$ & $\begin{array}{l}\text { Very dark body colouration, } \\
\text { slimy mucous secretions on } \\
\text { the gills and body surface; } \\
\text { peeling and skin erosion, } \\
\text { bleeding from the dorsal } \\
\text { fins and bending of the } \\
\text { caudal fin, some fins } \\
\text { became disintegrated }\end{array}$ & $\begin{array}{l}\text { Very dark body colouration, } \\
\text { slimy mucous secretions on } \\
\text { the gills and body surface; } \\
\text { peeling and skin erosion, } \\
\text { bleeding from the dorsal } \\
\text { fins and bending of the } \\
\text { caudal fin, some fins } \\
\text { became disintegrated }\end{array}$ & $\begin{array}{l}\text { Normal body colouration, } \\
\text { no morphological } \\
\text { abnormalities recorded. }\end{array}$ & $\begin{array}{l}\text { Normal body colouration, } \\
\text { no morphological } \\
\text { abnormalities seen }\end{array}$ \\
\hline Behavioural & $\begin{array}{l}\text { None as mortality } \\
\text { was recorded }\end{array}$ & $\begin{array}{l}\text { Erratic swimming, } \\
\text { accelerated operculum, } \\
\text { gasping, barbells vibration } \\
\text { and frequent coming } \\
\text { to the surface, } \\
\text { feeding impaired }\end{array}$ & $\begin{array}{l}\text { Erratic swimming, } \\
\text { accelerated operculum, } \\
\text { gasping, barbells vibration } \\
\text { and frequent coming } \\
\text { to the surface, } \\
\text { feeding impaired }\end{array}$ & $\begin{array}{l}\text { No behavioural } \\
\text { abnormalities observed. }\end{array}$ & $\begin{array}{l}\text { Normal movement } \\
\text { and behavioural } \\
\text { responses observed }\end{array}$ \\
\hline
\end{tabular}

fin, and disintegration of some fins, reduction in swimming speed and velocity, impairment in feeding and lethargy seen among the different life stages was attributed to the toxic effect of decreasing acidity on the body physiology. The morphological effects were more pronounced on the fingerlings due to their internal respiration where there is a direct contact between the acidified water and the internal organs. Moynan (1989) reported that bluegill larvae were less active at $\mathrm{pH}$ levels of 5.5 and the swimming was erratic, while Jordahl and Benson (1987) noted that domestic brook trout exhibited lethargic and/or uncoordinated swimming behaviour in response to acid exposure. Jones, Brown and Hara (1987) observed decreased attraction to food, reduced feeding, hyperactivity as some of the behavioural responses of fish to acid conditions. The survival and mortality recorded in the species could be linked to the morphological and behavioural responses of the fish in the different acidic media. These behavioural strategies and morphological adaptations could be the adaptive mechanisms which made the species to survive in the acidified waters by reducing the stress of the acid on them as noted by Flik et al. (1987).

\section{Conclusion}

This study has shown that mortality increases with decrease in $\mathrm{pH}$ and tolerance level of different life stages of O. niloticus increases with age. The research also shows that $O$. niloticus can be described as acid-tolerant species (acidophilic).

Although acid deposition and acid rain has not been well documented in many developing countries, there is no doubt that the phenomenon is present and on-going in the aquatic ecosystems of these countries. Researches should be geared towards understanding the phenomenon and its effects on water bodies and their biota.

A mitigating measure to the problem in the event of its occurrence is the reduction of emissions of oxides of sulphur and nitrogen. This could only be achieved through enactment of laws and implementation of acid pollution control strategies as done in developed countries. However, in the case, the lakes, rivers, streams, ponds and reservoirs have been identified as been acidic, liming of these water bodies could be done to raise the $\mathrm{pH}$ in order to remediate the fish populations from the effects of the acidity.

\section{Abbreviations}

ANOVA: Analysis of variance; $\mathrm{pH} / \mathrm{EC} / \mathrm{TDS} / \mathrm{Temp}$ : $\mathrm{pH}$, electrical conductivity, temperature

\section{Acknowledgements}

The authors would like acknowledge the laboratory staff that helped in the serial dilution of the stock solution.

\section{Funding}

This study was not funded by any institution, agency or entity.

\section{Availability of data and materials}

The datasets generated and analysed during the current study are available from the corresponding author on reasonable request.

\section{Authors' contributions}

MKM suggested the study and participated in its design and coordination. ADS carried out the acidification of the water, sample collection and analysis. MKM carried out statistical data analysis and interpret the results. MKM prepared the first draft of the manuscript. Both authors read and approved the final manuscript.

\section{Ethics approval}

All applicable international, national, and institutional guidelines for the care and use of animals were followed. All procedures performed in this study involving the fish Oreochromis niloticus were in accordance with the ethical standards of the University of Ilorin, Ilorin, Nigeria, where the study was conducted and who granted the ethical approval for the conduct of the research.

Consent for publication

Not applicable

Competing interests

The authors declare that they have no competing interests.

\section{Publisher's Note}

Springer Nature remains neutral with regard to jurisdictional claims in published maps and institutional affiliations. 
Received: 17 September 2018 Accepted: 1 November 2018

Published online: 14 November 2018

\section{References}

Alabaster, J. S., \& Lloyd, R. (1980). Water quality criteria for freshwater fish, European Inland Fisheries Advisory Commission Report (FAO) (). London-Boston: Butterworth.

Aride, P. H. R., Roubach, R., \& Val, A. L. (2007). Tolerance response of tambaqui Colossoma macropomum (Cuvier) to water pH. Aquaculture Research, 38(6), 588-594.

Baker, J. P., Sickle, J. V., Gagen, C. J., DeWalle, D. R., Sharpe, W. E., Carline, R. F., ... Wigington, J. P. J. (1996). Episodic acidification of small streams in the Northeast United States IV: Effects on fish populations. Ecological Applications, 6(2), 422-437.

Boyd, C. E. (1990). Water quality in ponds for aquaculture. Birmingham: Alabama Agricultural Experiment Station, Auburn University, Auburn: Birmingham Publishing Company.

Daye, P. G., \& Garside, E. T. (1980). Structural alterations in embryos and alevins of the Atlantic salmon, Salmo salar L. induced by continuous or short term exposure to acidic levels of pH. Canadian Journal of Zoology, 58, 27-43.

Duarte, R. M., Ferreira, M. S., Wood, C. M., \& Val, A. L. (2013). Effect of low pH exposure on $\mathrm{Na}$ + regulation in two cichlid fish species of the Amazon. Comparative Biochemistry and Physiology Part A: Molecular \& Integrative Physiology, 166(3), 441-448.

El-Sherif, M. S., \& El-Feky, A. M. I. (2009). Performance of Nile tilapia (Oreochromis niloticus) fingerlings. I. Effect of $\mathrm{pH}$. International Journal of Agriculture and Biology, 11, 297-300.

Flik, G., Kolar, Z., Van der Velden, J. A., Seegers, H. C. M., Seegers, C., \& Wendelaar, S. E. (1987). Sodium balance in the acid resistant east American mudminnow Umbra pygmaea (De Kay). In H. Witters, \& O. Vandeborght (Eds.), Ecophysiology of acid stress in aquatic organisms, (pp. 117-128). Brussels: Annales de la Societe Royale Zoologique de Belgique.

Hill, J., Foley, R. E., Blazer, V. S., Werner, R. G., \& Giannon, J. E. (1988). Effects of acidic water on young-of-the-year smallmouth bass (Micropterus dolomieui). Environmental Biology of Fishes, 21, 23-29.

Hirata, T., Kaneko, T., Ono, T., Nakazato, T., Furukawa, N., Hasegawa, S., ... Hirose, S. (2003). Mechanism of acid adaptation of a fish living in a pH 3.5 lake. American Journal of Physiology, 284, 1199-1212.

Jones, K. A., Brown, S. B., \& Hara, T. J. (1987). Behavorial and biochemical studies of onset and recovery from acid stress in Arctic char (Salvelinus alpinus). Canadian Journal of Fisheries and Aquatic Sciences, 44, 373-381.

Jordahl, D. M., \& Benson, A. (1987). Effect of low pH on survival of brook trout embryos and yolk-sac larvae in West Virginia streams. Transactions of the American Fisheries Society, 115, 807-816.

McKee, J. E., \& Wolf, H. W. (1963). Water quality criteria, (second ed., ). Sacramento: Water Quality Control Board Publication No. 3A.

Mount, D. I., Hockett, J. R., \& Gern, W. A. (1988). Effects of long-term exposure to acid, aluminum, and low caicium on adult brook trout (Salvenlinus fontinalis). 2. Vitellogensis and osmoregulation. Canadian Journal of Fisheries and Aquatic Sciences, 45, 1633-1642.

Moynan, K. M. (1989). In ) (Ed.), The effects of acid and water hardness on bluegill embryo-larvae determined by laboratory and on-site toxicity tests. Blacksburg: Virginia Polytechnic Institute and State University.

Nobre, M. K. B., Lima, F. R. S., \& Magalhães, F. B. (2014). Alternative liming blends for fish culture. Acta Scientiarum. Animal Sciences, 36(1), 11-16.

Peterson, R. H., \& Martin-Robichaud, D. S. (1986). Growth and major inorganic cation budgets of Atlantic salmon alevins at three ambient acidities. Transactions of the American Fisheries Society, 115, 220-226.

Rask, M. (1984). The effect of low pH on perch, Perca fluviatilis L. II. The effect of acid stress on different development stages of perch. Annales Zoologici Fennici, 21, 9-13.

Rebouças, V. T., Lima, F. R., Cavalcante, D. H., \& Sá, M. V. C. (2015). Tolerance of Nile tilapia juveniles to highly acidic rearing water. Acta Scientiarum. Animal Sciences, 37(3), 227-233.

Sivaramanan, S. (2015). Acid rain, causes, effect and control strategies. https://doi. org/10.13140/RG.2.1.1321.4240/1.

USEPA (1986). Quality criteria for water. Washington, D.C.: Office of Water Regulations and Standards.

Wangead, C., Geater, A., \& Tansakul, R. (1988). Effects of acid water on survival and growth rate of Nile tilapia (Oreochromis niloticus). In S. V. Puulin, T. Bhukaswan, T. Tonguthai, \& J. L. Maclean (Eds.), Second International
Symposium on Tilapia in Aquaculture: Physiology; 1987, March 16-20, Bangkok, Thailand, (pp. 433-438). Manila: ICLARM.

Wood, C. M., \& McDonaild, D. G. (1982). Physiological mechanisms of acid toxicity to fish. In T. A. Haines, \& R. E. Johnson (Eds.), Proceedings / International Symposium on acidic precipitation and fishery impact in northeastern North America: Physiology; 1981, August 2-5, Ithaca, New York, (pp. 179-226). Bethesda: American Fisheries Society.

\section{Submit your manuscript to a SpringerOpen ${ }^{\circ}$ journal and benefit from:}

- Convenient online submission

- Rigorous peer review

- Open access: articles freely available online

- High visibility within the field

- Retaining the copyright to your article

Submit your next manuscript at $>$ springeropen.com 